\title{
Entre "alegres" e "livres": prazer e repressão à pornografia nos cinemas do Rio de Janeiro (1907-1916)
}

\section{Pedro Vinicius Asterito Lapera}

Fundação Biblioteca Nacional, Rio de Janeiro, Rio de Janeiro, Brasil Universidade Federal Fluminense, Niterói, Rio de Janeiro, Brasil

\section{Resumo}

Este artigo aborda as articulações entre consumo cinematográfico, pornografia e público no Rio de Janeiro durante a Belle Époque, mais precisamente a partir de duas questões: de que modos a exibição cinematográfica condicionou o consumo de obras consideradas pornográficas? E como as campanhas de repressão à pornografia nos cinemas atuaram nesse consumo? Partimos da hipótese de que o consumo de filmes pornográficos foi percebido como uma poluição em relação ao ritual de ir ao cinema. Em uma escala maior, esse consumo também pode ser percebido como uma poluição às concepções de honra sexual vigentes no período. Como metodologia, adotamos o paradigma indiciário, tal como exposto por Carlo Ginzburg. Como resultados, destacamos a inserção da repressão à pornografia dentro do projeto higienista para o Rio de Janeiro, das disputas entre teatro e cinema e de uma moral cara aos setores médios em formação.

\section{Palavras-chave}

Cinema silencioso. Pornografia. Consumo.

\section{Introdução}

Nas primeiras décadas do século $\mathrm{XX}$, os moradores do Rio de Janeiro testemunharam a consolidação da presença dos cinematógrafos na paisagem urbana carioca. Imersos em uma reforma projetada para higienizar as regiões mais centrais e prósperas da presença das classes populares, estas casas de diversão foram rapidamente eleitas como o ponto de encontro de sujeitos pertencentes a diferentes grupos.

Embora este artigo esteja situado dentro de um projeto de pesquisa mais amplo sobre consumo cinematográfico no Rio de Janeiro nas primeiras décadas do século XX, não podemos perder de vista o fato de que ele foi pensado em um momento no qual algumas concepções bastante cristalizadas em torno da pornografia e do prazer sexual retornam aos debates públicos em diferentes meios de comunicação, de modo a tentar tolher a criação artística e a constranger artistas e instituições. Acionar os vestígios da repressão 
ao consumo de filmes pornográficos pode ser percebido como um esforço intelectual de remontar a um momento histórico em que essas questões emergiram em uma cena pública altamente hierarquizada em termos de classe, gênero, raça e nacionalidade.

O objetivo deste artigo é tentar compreender as articulações entre consumo cinematográfico, pornografia e público, mais precisamente a partir de duas questões: de que modo a exibição cinematográfica conformou o consumo de obras consideradas pornográficas? E como as campanhas de repressão à pornografia nos cinemas atuaram neste consumo?

Para fins desta exposição, adotamos a definição de Douglas e Isherwood (2004) sobre consumo, que o apontam como uma atividade ritual usada para demarcar julgamentos e fronteiras sociais e que confere estabilidade às categorias culturais espacial e temporalmente. Partimos da hipótese de que o consumo de filmes pornográficos foi percebido como uma poluição em relação ao ritual de ir ao cinema, no sentido atribúido por Douglas (1976), que a considera como uma desordem de elementos que deveriam ser arranjados de outra forma. Em uma escala maior, esse consumo também pode ser percebido como uma poluição às concepções de honra sexual vigentes no período (CAUlField, 2000).
O recorte entre 1907 e 1916 foi escolhido a partir do fato de que 1907 marcou a inauguração da primeira sala exclusivamente dedicada à exibição cinematográfica - o Cinema Parisiense (ARAÚJo, 1985) -, englobando a primeira década da presença dos cinemas na então Capital Federal. Além disso, houve uma crise de fornecimento de fitas cinematográficas por conta da Primeira Guerra Mundial, cujos efeitos foram sentidos pelo mercado exibidor em 1916, marco temporal que encerra nossa exposição.

É preciso sublinhar que recuperamos algumas fontes veiculadas pela imprensa da época, que desempenhavam um papel importante na disseminação dos debates projetados na cena pública do Rio de Janeiro da Primeira República. Em geral, jornais surgiram no final do Império e no início do regime republicano como plataforma de ideias liberais em termos econômicos e políticos (BARBOSA, 2007), o que não impediu que veiculassem artigos e editoriais que partilhassem pontos de vista conservadores e conectados com instituições como a Igreja Católica. Afinal, como disse Ginzburg (1998, p. 31), "as crenças antigas não se dissolvem facilmente”.

Em paralelo, o consumo de produtos relacionados à pornografia (livros, revistas, fotografias) era um fenômeno crescente desde a segunda metade do século XIX (EL FAR, 2004), sendo potencializado pela exibição cinematográfica e atraindo uma população 
jovem masculina e até mesmo mulheres que conseguiam burlar o controle de pais e maridos e acessar essas obras. Tal fato não passou despercebido pelos articulistas dos jornais da época nem pelas autoridades municipais e federais, que condenavam tanto a pornografia quanto quem se predispunha a entrar em contato com ela ${ }^{1}$.

A conexão entre micropráticas e macroprocessos foi apontada por John e Jean Comaroff (1992) como necessária ao fazer etnográfico em arquivos, na medida em que as "histórias parciais [coletadas pelo pesquisador], 'escondidas' precisam ser situadas nos mundos mais amplos de poder e de significado que as deram vida" (p. 17, tradução nossa). Seguindo essa linha, compreender a poluição em diferentes escalas perpassa a investigação tanto de aspectos da exibição cinematográfica quanto dos motivos pelos quais a pornografia era considerada uma poluição e quais ideias de pureza (DougLAS, 1976) eram atingidas por ela - e, sobretudo, quem as defendia e a que grupos pertencia.

Em relação ao tratamento das fontes, já expusemos em outra oportunidade (LAPERA;
SOUZA, 2010) que esta pesquisa utiliza o paradigma indiciário, tal como pensado por Ginzburg (2007). Mesmo tendo em vista a heterogeneidade das fontes e das informações coletadas, é possível reuni-las caso sejam consideradas vestígios de processos de estruturação e de mudança social (GINZBURG, 2007a).

Além disso, reconhecemos nossa dívida com o trabalho de El Far (2004) sobre romances pornográficos entre o fim do século XIX e o início do xx, já adiantando uma ausência em nossa pesquisa: ao contrário dos romances pornográficos precariamente preservados, os filmes pornográficos aos quais algumas fontes fazem menção estão desaparecidos, sendo impossível tentar buscar algumas chaves de leitura presentes nessas obras.

Os vestígios que sobreviveram ao tempo remetem ao discurso dos detratores do consumo pornográfico. Deste modo, apresentamos a ambiguidade da nossa exploração. Não encontramos em nenhuma das fontes uma defesa aberta do consumo da pornografia, embora todas reconheçam explícita ou implicitamente que a frequência aos cinemas

1 Inclusive, El Far (2004) delimita que era considerado material pornográfico qualquer peça que apresentasse conteúdo sexual e/ou nudez durante o período avaliado em sua pesquisa. Embora consideravelmente menor, o período abordado em nosso artigo coincide parcialmente com o da autora, por isso optamos em adotar a sua definição de material pornográfico.

2 "these partial, 'hidden stories' have to be situated in the wider worlds of power and meaning that gave them life". 
para ver filmes "alegres" ou "livres" (termos muitas vezes usados como eufemismos para pornográfico) era alta. Transitar pelos rastros do discurso de quem queria reprimir a pornografia para tentar minimamente captar as expectativas do público em torno dela é, portanto, o desafio a que nos lançamos.

Antes de passarmos à exposição, precisamos traçar um breve panorama das fontes selecionadas para este artigo ${ }^{3}$. Trata-se de 27 fontes veiculadas por 14 publicações que circulavam pelo Rio de Janeiro durante as primeiras décadas do século XX coletadas no acervo físico ou na Hemeroteca Digital da Biblioteca Nacional. Artigos, editoriais, notícias e cartas de leitores presentes em jornais de grande circulação (Jornal do Brasil, Correio da Manhã, Jornal do Commercio, Gazeta de Notícias), revistas satíricas (Careta, O Malho) e publicações consideradas pornográficas por seus contemporâneos (O Rio Nu).

\section{Prazeres e perigos na ida ao cinema no Rio de Janeiro da Belle Époque}

Ao folhear um jornal carioca do início do século XX, o leitor encontrava fartamente reclames de teatros e cinemas anunciando peças e filmes do gênero "livre" e "alegre". Via de regra, referiam-se a obras de viés cômico ou de variedades, relacionadas a temas do cotidiano ou fait divers veiculados pelos periódicos. Todavia, os termos poderiam esconder um truque. Como os exibidores e empresários teatrais não podiam anunciar nos jornais conteúdos expressamente pornográficos, sob pena de serem censurados pelos jornais e perseguidos pelas autoridades policiais, tais adjetivos eram usados para camuflar aos espectadores mais recatados as peças e os filmes mais picantes ${ }^{4}$.

Além da ambiguidade dos termos, a descrição muitas vezes discreta do conteúdo dos filmes também poderia gerar situações inusitadas e, às vezes, constrangedoras para alguns frequentadores dos cinemas. Um leitor inconformado com o fato de não ter sido avisado escreveu indignado ao jornal da Gazeta de Notícias, que publicou sua carta:

\author{
No Odeon \\ Os filmes obscenos
}

'Sr. redactor da "Gazeta de Noticias" Sendo como sou frequentador de cinemas, bem como a minha familia, fui hontem, accidentalmente ao odeon, sem me ter

3 Essas fontes não fazem parte necessariamente do corpo deste artigo, mas foram coletadas a partir das questões levantadas aqui.

4. El Far (2004) relata a existência de leis visando coibir o comércio de obras pornográficas e a atuação de agentes policiais voltados exclusivamente para a repressão à pornografia. 
dado primeiramente ao cuidado de ver 0 programma e o titulo da peça que se desenrolaria na tela.

Ah!, Sr. redactor, não é possivel num simples relato dizer-lhe a indignação de que, subitamente, me tomei, ante a pouca vergonha que a fita revela e o pouco escrupulo do dono ou donos do cinema, não declarando, em aviso prévio, que " 0 culto da belleza" é uma fita exclusivamente para homens!!!

As minhas filhas - uma de 17 e outra de 19 annos - sahiram do Odeon immediatamente, pois que tal fita não póde absolutamente agradar a meninas que têm pudor e não desejam ser, assim, canalhamente, offendidas no seu recato.

Mas, como estamos numa terra em que da liberdade se faz um perenne abuso e a policia não se preoccupa com a moralidade social, não é de estranhar o que se passa no Odeon. Não peço providencias porque requisital-as do Sr. chefe de policia seria chover no molhado...

Insisto, porém, Sr. redactor, em sollicitar da "Gazeta", a gentileza de reverberar ainda uma vez, com o grande peso da tradicional austeridade essa desfaçatez.

Realmente, Sr. redactor, é necessario que as familias estejam acauteladas dessas patifarias sem nome. Fitas como a que venho alludindo só se expõem depois de claramente divulgadas com 0 aviso de que são unicamente "genero livre".
Assim, evitar-se-á o desgosto de passar um pobre chefe de familia pelo vexame a que fui submettido hontem, aliás, pela minha inadvertencia.

Outro ponto que merece referencia é o das traducções das legendas. Que horror!

Sobre elle precisa também a autoridade incumbida de velar pela moralidade publica providenciar efficazmente.

Dando guarida ás linhas que lhe dirijo, revoltado contra o abuso dos cinemas exhibirem films que constituem graves achincalhes á moralidade, tenho o prazer de subscrever-me leitor attento e assiduo. - M.A.F ${ }^{5}$.

Algumas chaves de leitura sobre o consumo de pornografia e o domínio do prazer podem ser extraídos desta carta. O termo "gênero livre" é usado pela carta para se referir a filmes considerados pornográficos, o que situa o adjetivo dentro da experiência do público de cinema no início do século $\mathrm{XX}$. O espectador demonstra que se trata de um sinal importante para que ele pudesse decidir sobre os filmes a que sua família assistiria e, embora a expressão se situe em um campo semântico ambíguo, fica claro que não foi esta o motivo da confusão no caso específico. 
Sobre a expressão, ainda podemos sublinhar que se tratava de um importante demarcador do consumo de fitas vistas como pornográficas acionado pelos espectadores. Esta colocava-se como prática de comunicação entre exibidores, anunciantes e público, mais precisamente como uma forma de sublinhar um tipo de consumo que, embora não tivesse amparo nos rígidos códigos morais vigentes, era tolerado e até mesmo esperado por quem explorava o comércio de filmes.

Na carta, também é destacado quem deve ser objeto da tutela do pai: a família, mais especificamente suas filhas. Para que elas não fossem "canalhamente ofendidas em seu recato", caberia à figura paterna zelar pelo conteúdo ao qual elas deveriam acessar no consumo cinematográfico e, assim, a família seria a entidade a ser protegida. Parafraseando Douglas (1976), os objetos e o conteúdo do ideal de pureza para os espectadores de cinema do período começam a ser delineados.

Em relação a isso, é possível adicionar que o espectador revoltado refere-se ao filme como uma "fita exclusivamente para homens", com muitas exclamações enfatizando a expressão para homens. O destaque dado ao fato de que o consumo de filmes pornográficos deveria ser exclusivamente destinado aos homens - em consequência, as mulheres estariam excluídas do mesmorevela que o os códigos referentes ao prazer sexual eram concebidos como necessariamente circunscritos a eles. Para o autor, era um pressuposto de que só homens poderiam consumir pornografia. Sua indignação não reside na existência do conteúdo pornográfico nem no fato de tê-lo visto, mas em não ter podido coibir a presença de suas filhas no cinema diante do conteúdo pornográfico. Inclusive, o autor admite implicitamente que viu o filme considerado impróprio por ele, a ponto de propor retificações na sua legenda.

Em oposição, as mulheres que ultrapassassem alguns limites e acessassem esses códigos não seriam mais consideradas plenas em sua honra sexual (CAULFIELD, 2000). Assim, as filhas do autor irascível da carta eram consideradas pela autoridade paterna como excluídas da fruição dos códigos e produtos relacionados à pornografia, uma postura metonímica vinculada a grupos sociais específicos, conforme analisaremos adiante. Neste ponto, o consumo de fitas pornográficas pode ser visto como delimitado pelas práticas discursivas referentes às relações de gênero tal como difundidas à época e, assim, a apropriação dos repertórios das fitas pornográficas pode ser vista como uma prática comunicativa 
eminentemente (embora não exclusivamente) masculina ${ }^{6}$.

A carta também infere que o Estado deveria ter mecanismos de controle sobre a difusão de conteúdos da pornografia, ao reclamar que as autoridades policiais não seriam zelosas o suficiente para coibir a exibição de filmes pornográficos e ao considerá-la abusiva, defendendo implicitamente a censura deste tipo de obra nos cinemas da cidade. Além disso, ainda há o apelo às autoridades policiais que, embora apareçam desacreditadas nas palavras do autor da carta, são tidas como garantidoras da ordem nesse espaço urbano. Por fim, revela uma crença no papel da imprensa e dos jornalistas como mantenedores da ordem pública, uma vez que o apelo é dirigido ao editor do jornal.

Ainda, podemos especular sobre a autoria da carta. Embora a carta seja assinada por uma sigla (M.A.F.), o que nos impede de identificar sua autoria, os fatos de o autor se reconhecer como espectador assíduo dos cinematógrafos e de levar sua família para se divertir neles, além do vocabulário um tanto rebuscado da carta e de seu estilo ser formal podem ser considerados indícios de que este pertenceria aos estratos sociais médios ou superiores - possivelmente, um burocrata ou um comerciante ou um profissional liberal. Mas o traço mais revelador do pertencimento de classe do autor é o tratamento dado ao editor do jornal, sendo visto em pé de igualdade em relação ao seu interlocutor.

Antes de passarmos a outros aspectos de nossa exposição, precisamos explicitar alguns motivos que pautaram as nossas escolhas em torno das fontes. Reconhecemos que uma mensuração quantitativa em torno do mercado de cinema voltado a obras pornográficas no período abordado mostra-se impossível, em virtude da ausência de alguns tipos de fontes oficiais e/ou administrativas ${ }^{7}$.

Além disso, os jornais que circulavam à época deixaram disponíveis uma massa de informação enorme e bastante assimétrica, que impede o tratamento em conjunto destes como séries documentais. Deste modo,

6 Precisamos observar que consideramos esta apropriação dos repertórios ligados à pornografia como uma prática comunicativa, na medida em que ela era capaz de ser disseminada pelas redes de sociabilidade e também de se inserir na teia de significados referentes sobretudo à experiência masculina, em razão dos códigos de honra vigentes à época. Isto é, na conformação de uma identidade de gênero na vida cultural do Rio de Janeiro durante a Primeira República, esses repertórios precisavam ser comunicados e ressignificados através das experiências dos sujeitos.

7 A título de exemplo, não conseguimos encontrar levantamentos de censura feitos pelas forças policiais, balancetes de empresas que exploravam filmes pornográficos nem autos de apreensão desses filmes. 
o paradigma indiciário surge como um modelo de crítica textual que nos permite a seleção de algumas fontes que abordaram o consumo de obras pornográficas sob a ótica dos espectadores, dos cronistas e de alguns empresários ligados à atividade cinematográfica, tais como a carta do leitor que analisamos.

Essas fontes dispersas ganham relevância justamente por permitirem acessar algumas disposições em relação ao consumo de filmes pornográficos. Não queremos com isso suprir as lacunas deixadas pela ausência de outros tipos de fontes. Pelo contrário, filiamo-nos ao que já foi exposto por Ginzburg a respeito de seu método: "a microhistória escolhe a abordagem inversa. Ela aceita as limitações [da profissão de historiador] enquanto explora suas implicações gnosiológicas e as transforma em um elemento da narrativa"8 (GINZBURG, 1993, p. 28, tradução nossa).

Sobre a frequência aos cinemas, embora a população mais pobre não fosse impedida de ir às casas de espetáculos no Rio de Janeiro do início do século XX, alguns constrangimentos dificultavam que isso se conformasse como um hábito de lazer. Chalhoub (2012) abordou a escassez da renda destinada ao lazer nas classes populares e, a isto, acrescentamos que a ida aos cinemas não era uma diversão muito barata se comparada a outras disponíveis a elas (por exemplo, bares e cafés-concertos), além de demandarem vestimentas e acessórios caros para os padrões dessas classes.

A partir da inauguração da primeira sala dedicada à exibição de cinema, o mercado de exibição cinematográfica estruturou-se nas áreas centrais recém-reformadas pelo então prefeito Pereira Passos, nos bairros da Zona Sul e nos subúrbios, mais especificamente nas regiões mais próximas à linha férrea da Central do Brasil. Mesmo reconhecendo a heterogeneidade desse público, é possível inferir a partir dos anúncios veiculados pelos jornais que havia diferenciação quanto aos preços de lugares em um cinema (primeira e segunda classes, a segunda custando a metade da primeira, via de regra) ${ }^{9}$.

Ter em vista esse recorte é importante para compreender quais são os sujeitos alvos do ideal de pureza que se afirmava a partir das concepções em torno de família e de honra sexual na Primeira República e como estas

8 "Michohistory chooses the opposite approach. It accepts the limitations while exploring their gnoseological implications and transforming them into a narrative element".

90 preço dos ingressos variava entre 1000 réis para a primeira classe e 500 réis para a segunda classe, em média. 
se relacionam com o consumo cinematográfico no período abordado. Em razão da presença relativamente recente da tecnologia do cinema no cotidiano das grandes cidades pelo mundo, era possível ler alguns artigos e matérias nos jornais de grande circulação sobre alguns efeitos dos filmes considerados nefastos na socialização das crianças e jovens, sobretudo no aumento da criminalidade por parte destes ${ }^{10}$.

Alguns comentaristas também demonstravam preocupação com a exposição de crianças a conteúdos pornográficos. Elogiando a atuação da polícia na repressão a exibições de filmes pornográficos, a matéria do jornal O Paiz publicada na capa da edição de 12.6.1911 pondera que "estas eram, ao menos, a portas fechadas e iam assistil-as voluntariamente cidadãos cuja moral a policia não precisava mais defender". Dessa maneira, contrapõe seu objetivo: atacar as publicações pornográficas que, ao contrário dos filmes, eram expostas publicamente em bancas de jornal pela cidade, atraindo os olhares dos curiosos. O cerne do argumento da matéria refere-se a quem deve ser evitado o consumo desses itens:
Para estas precisa olhar a policia; olhar e pôr em pratica as suas boas intenções de defesa da moral publica, ou melhor da dignidade das senhoras e da educação das crianças, diante de cujos olhos se ostentam insolentemente, com uma liberdade só concebível entre nós, as edições as mais despudoradas. Senhoras e crianças, quando não se deva cogitar do simples decoro collectivo, são insultadas no seu pudor, umas, e pervertidas na sua educação, outras, por essa ostentação de gravuras livres em plena rua, a ferir a attenção dos que possam pelo destaque da sua nudez obscena. A policia tem obrigação de corrigir este abuso ${ }^{11}$.

O trecho transcrito explicita que mulheres e crianças são os potenciais alvos do controle em torno do consumo de obras e produtos pornográficos. No entanto, precisamos verificar se este tipo de controle era amplamente aplicado a estes grupos ou se, em certa medida, havia alvos mais específicos desse controle. Em outras palavras, analisar se o ideal de pureza da Primeira República abarcava as mulheres e as crianças em sua totalidade ou se era reservado a um grupo específico de mulheres e de crianças ${ }^{12}$ e, ainda, como o potencial comunicativo das obras pornográficas era abordado pelos cronistas.

10 E.g. Jornal do Commercio. 23.7.1910, p. 1 e Os cinematographos. A Pátria Brazileira, 24.7.1910, p.2.

11 O Paiz, 12.6.1911, p. 1.

12 Hunt (1999) e Kendrick (1997) argumentam que a censura - institucionalizada ou informal -, a regulação e os hábitos de consumo massivo foram fundamentais para determinar o conteúdo da pornografia na modernidade ocidental. 
Ao se debruçar sobre a detenção de menores e a construção social da categoria menor no Rio de Janeiro, Vianna (1999) identificou na virada entre os séculos XIX e Xx como o período em que os menores passaram a ser vistos como um problema pelas autoridades e pelos legisladores. Neste cenário, “ [...] as 'crianças desvalidas' eram foco de intervenção de diferentes profissionais, ao mesmo tempo que objeto de novas regulamentações legais" (VIANNA, 1999, p. 42). A autora identificou que esses menores eram em sua vasta maioria oriundos das massas recém-libertas da escravidão e das classes operárias nacionais e estrangeiras que, por suas condutas, eram enquadrados nos estereótipos associados às "classes perigosas" e, portanto, passíveis de encarceramento (VIANNA, 1999).

As pistas reveladas ao longo do trabalho de Vianna (1999) nos levam a inferir que esses menores - embora alvo de um controle disciplinar por parte das instituições do Estado estavam fora do ideal de pureza em torno das crianças no período analisado. Inclusive, eles deveriam ser excluídos do domínio do lazer e do consumo, considerados um risco à formação do seu caráter, uma vez que o ócio era visto como uma oportunidade para práticas delituosas. Sendo assim, para os menores era reservado o discurso da regeneração pelo trabalho e pela educação, cabendo às autoridades policiais e educacionais zelar por eles.
Desse modo, a proteção requerida pelos articulistas dos periódicos cariocas contra a pornografia assume um recorte mais específico. A infância a ser tutelada passa pela projeção de um ideal de pureza em crianças das classes superiores, não somente porque elas eram os potenciais espectadores dos cinematógrafos - em virtude de seus pais também o serem e proverem seus filhos com recursos para este tipo de lazer -, mas principalmente por se situarem em um tropos de classe e de raça valorizado à época, relacionado ao ideal civilizatório da Primeira República. Neste ponto, precisamos recordar que um ideal de branqueamento da população brasileira afirmado acadêmica e burocraticamente (SCHWARCZ, 2005) era projetado nas práticas sociais, fazendo-se presente em vários níveis. Logo, era reservado o lugar de cidadãos do amanhã a estas crianças específicas, que deveriam ter sua formação intelectual poupada do consumo de pornografia, uma vez que esta representava um perigo à formação de seu caráter e, metonimicamente, da nação brasileira a ser projetada no futuro.

Além das crianças, as mulheres também são mencionadas como um grupo a ser preservado do contato com obras pornográficas. Ao pesquisar sobre as noções em torno da honra sexual, Caulfield (2000) argumentou que havia duas noções em torno dela (recurso familiar e virtude individual) capaz de gerar 
algumas confusões tanto na interpretação legal quanto nas práticas sociais e discursivas a seu respeito. Sobre isso, infere a autora: “[...] a honra como precedente era a prerrogativa dos homens, a honra como atributo moral (pureza sexual) era restrita às mulheres, e a defesa da honra feminina, uma responsabilidade masculina" (p. 86).

Por sua vez, Abreu (2016) pondera que havia dois estereótipos muito fortes em relação à conduta das mulheres na Primeira República: a mulher solteira ou casada recatada e sexualmente contida e a prostituta dotada de um comportamento público histriônico e uma sexualidade latente e perigosa. Assim, os contornos à interdição do consumo de filmes pornográficos e, por extensão, da ida a cinematógrafos que os projetem, parecem ficar um poucos mais claros e, neste contexto, as mulheres pertencentes aos estratos médios e superiores e não relacionadas à prática da prostituição mostram-se como o alvo dessa interdição.

Deste modo, é possível perceber a exclusão do consumo de fitas pornográficas em dois níveis, o que atenuaria o potencial comunicativo dessas obras. Em um primeiro nível, ligado ao domínio econômico, mulheres e crianças pobres estariam excluídas pelo acesso precário à diversão cinematográfica. Por sua vez, em um segundo nível, no qual há um acesso às salas de cinema, o controle de ordem moral seria acionado para evitar a 'contaminação' de crianças e mulheres dos estratos sociais superiores.

A perseguição à pornografia ocorria em um ambiente urbano muito hierarquizado, sobretudo após as reformas empreendidas pelo prefeito Pereira Passos, no sentido de afastar as classes mais pobres das áreas centrais e nobres do Rio de Janeiro. Evidentemente, tal processo não ocorreu sem tensões nem disputas. Na coluna Kaleidoscopio do Jornal do Brasil de 10.4.1910, foi publicado um conto sobre a trajetória de um barracão que persistia em se manter no meio da Avenida Central, símbolo do progresso que a gestão Passos pretendia trazer aos trópicos. Narrando a vida desse barracão, alguns trechos merecem destaque:

Que bruxa caprichosa e potente protegeu esse parasita, em lucta com a fada que transformou a cidade, espalhando-se no seio a vida progressiva, derrocando velharias e erguendo verdadeiros templos de arte, exemplares de architectura, primores de construcção, remodelando a metropole do aspecto secular tirando-Ihe a physionomia colonial, convertendo-a em um grande jardim que se espelha nas aguas da bahia sem par, enchendo o espaço de zimborios e minaretes rutilantes desvendando horizontes inigualaveis, tornando-a um dos mais bellos e pomposos recantos do mundo, aproveitando com insuperavel maestria a moldura das montanhas e os encantos naturaes que a tornam sem rival no mundo. 
[...] 0 facto é que ali o tivemos a afeiar, em uma inconcebivel pertinencia, por mais de um lustro, a Avenida aberta ao sol, e depois de ser o panorama execravel converteu-se em café-concerto e cinematographo livre, e é agora um cinematographo commum, de bons costumes, recatado e honesto, como que alimentando o proposito de apparecer aos olhos do juiz perante quem responde pelos seus feios delictos, como um regenerado que pelo seu arrependimento quer continuar a merecer uma protecção que ameaça fugir-Ihe.

Sim, porque afinal, surgiu um protesto contra suas demasias. A cidade não podia continuar com essa mancha tão negra na face formosa e remoçada. E appellou para a Justiça. Cumpria libertal-a do verme que Ihe devorava friamente a belleza que tão caro lhe custara ${ }^{13}$. (grifo nosso)

Além de situar o progresso como valor a ser perseguido no espaço urbano carioca, a crônica transforma o barracão em um personagem que desafia as regras de contenção ao ser um "cinematographo livre" e, por oposição, civiliza-se e se torna "comum", "recatado" e "honesto"14. A higienização das zonas centrais passou pela perseguição às exibições de filmes pornográficos e, em um sentido mais amplo, às demonstrações explícitas do domínio do prazer e do excesso. A transformação narrada resume o constrangimento legal ao qual o espaço foi submetido para que sua existência continuasse a ser permitida neste novo projeto de Capital.

A lição moral do conto com a frase "cumpria libertal-a do verme que lhe devorava friamente a belleza que tão caro lhe custara" remete às expectativas em torno das transformações urbanas pelas quais o Rio de Janeiro passou na primeira década do século $\mathrm{XX}$, sobretudo às das classes superiores. Sevcenko (1983) considerou que a área central da então Capital Federal deveria ser o símbolo do progresso da Primeira República, devendo ser preservada de práticas ligadas à cultura popular e de sujeitos das classes mais baixas. Segundo o autor, qualquer signo que remetesse a elas era visto como poluição: "as barracas e quiosques que exasperam público e cronistas são os que localizam 'no perímetro central da cidade'. As favelas que aterrorizam são as visíveis da Avenida Central" (p. 34). Nesse momento, a pornografia é vista como um signo do excesso a ser removido das áreas mais civilizadas da cidade, associada ao "verme", à sujeira que polui o ritual de ir ao cinema. Porém, reconhecem-se as práticas comunicativas entre alguns grupos em

13 Jornal do Brasil, 10.4.1910, p. 8.

14. Vale ressaltar que, em comparação com outras fontes, a crônica refere-se ao Concerto Avenida, casa de espetáculos de propriedade de Paschoal Segreto, um dos grandes empresários do entretenimento carioca do qual ainda falamos em nosso artigo. 
torno do seu consumo e, por isso, detecta-se o perigo sobre a sua disseminação massiva.

Dentro desta higienização do espaço urbano, Sevcenko (1983) considerou que elementos caros à cultura popular como o Carnaval, os ritos religiosos de origem africana, as festas de santos católicos e outros relacionados à religiosidade popular, capoeira, dentre outros, também deveriam ser afastados ou passar por uma releitura etnocêntrica que os tornasse mais europeu. No caso do Carnaval, este era visto como " [...] o da versão europeia, com arlequis, pierrôs e colombinas de emoções comedidas, daí o vitupério contra os cordões, os batuques, as pastorinhas e as fantasias populares preferidas: de índio e de cobra viva" (SEVCENKo, 1983, p. 33).

Neste Carnaval europeizado, o controle da exibição de algumas partes do corpo fazia-se presente através não apenas das fantasias - o apelo erótico/fálico da fantasia de cobra viva a ser banido - como também o pornográfico deveria ser rechaçado, tal como ocorreu segundo uma crônica publicada no jornal O Paiz sobre os desfiles daquele ano na Avenida Rio Branco: "Ainda um carro de critica, "charge", bella feita à exhibição de fitas "genero livre" em alguns cinematographos [...]"15.
Apropriando-se do potencial comunicativo de um gênero visual popularizado pelo jornalismo das primeiras décadas do século XX, esse carro no Carnaval mostrou-se veiculador da visão de ordem do então nascente regime republicano, ao condenar a vista de filmes pornográficos. Lembramos que a Avenida Central era um espaço ocupado prefencialmente pela elite e pelos setores médios, sobretudo em datas festivas e em momentos fora dos horários de trabalho de sujeitos ligados às classes populares.

Ginzburg (2007b) nos recorda do valor etnográfico de alguns dados residuais presentes nos processos da Inquisição contra camponeses da região do Friuli (Itália). Em resumo, o autor argumenta que, ultrapassando as formas dos documentos contidas nesses processos, alguns sinais permitiam o acesso a uma realidade cultural complexa.

Apropriando-nos da reflexão do autor, podemos inferir que as fontes apresentadas neste artigo expõem alguns sinais que nos permitem acessar algumas das barreiras morais impostas ao consumo de pornografia no período abordado. Cruzando esses sinais com as interpretações elaboradas por outros historiadores que se debruçaram sobre 
diferentes aspectos da sociedade carioca na Primeira República, é possível conectá-los a outros dados estruturantes dessa mesma sociedade. Isto é, atemo-nos ao objetivo do paradigma indiciário proposto pelo historiador, no sentido de usá-lo “ [...]como um instrumento para dissolver as névoas da ideologia que, cada vez mais, obscurecem uma estrutura social como a do capitalismo maduro" (GINZBURG, 2007a, p. 177).

Além das áreas centrais, a perseguição à pornografia migrou para os subúrbios, uma vez que o ideal civilizatório colocado em prática pela reforma urbana conquistou adeptos entre cidadãos das diversas classes sociais e regiões da cidade. Um relato disso foi publicado no Jornal do Brasil:

De S. Francisco Xavier a Santa Cruz, a cada passo, encontram-se cinemas funccionando em acanhados, anti-hygienicos e desgraciosos barracões de madeira, alguns cobertos de zinco, com a lotação não raras vezes escondidas e o que peiora mais, esse estado de cousas explorando fitas de genero livre.

Eis, pois, a falta de segurança aliada a uma condemnavel licenciosidade.

Está na alçada da policia intervir no caso com a maxima urgencia e energia, garantindo a vida de incautos frequentadores e evitando ao mesmo tempo a continuação de espectaculos dessa ordem, verdadeira escola de perversão de menores, embora façam as delicias da vadiagem perigosa que infesta os referidos bairros ${ }^{16}$.

A perseguição política, administrativa, judicial e policial à pornografia estava na agenda dos idealizadores e dos mantenedores da ordem na Primeira República. El Far (2004) analisou uma série de medidas que visavam impedir o consumo de filmes, publicações e peças pornográficas, tais como a criação da Liga AntiPornographica em 1912 e de outras associações semelhantes relacionadas à Igreja Católica.

Outra associação nesta linha, o Círculo Catholico encabeçou uma petição publicada no jornal O Paiz endeçada a Nilo Peçanha - então Presidente da República ${ }^{17}$. Posicionando-se contra a "corrupção da índole do povo" e a "afronta do pudor público" por "máos estrangeiros que, ao envez dos muitos e bons que nos auxiliam e se fazem nossos irmãos, de boa mente aqui se enriquecem, armando em nossas cidades prostíbulos e jogatinas ou corrompendo-nos com exhibições desonestas", a petição solicitava a aplicação de leis já 
existentes para combater a exibição e a importação de obras pornográficas.

Além disso, setores ligados à Igreja atuavam na censura a filmes que pudessem veicular algum tipo de conteúdo pornográfico. No artigo Contra a Pornographia, publicado no jornal A União, é descrito o processo de censura ao filme $O$ maduro. Sem maiores referências ao conteúdo da obra, o artigo faz menção à presença de um sacerdote católico na revista promovida pela polícia e que o filme foi vetado à exibição por conta da presença de críticas severas às instituições e de "offensas à moral pública", uma vez que "a pornographia em algumas phrases era um facto" ${ }^{18}$. Isso significava que alguns setores da elite carioca temiam a disseminação dessas fitas por mais grupos sociais além do que já era tolerado pelas instâncias administrativas, na medida em que reconheciam o potencial comunicativo dessas obras em interpelar um público maior.

Encontramos várias fontes que aludem a projetos de lei e medidas de ordem administrativa visando combater o consumo de pornografia. Um artigo no Correio da Manha ${ }^{19}$ atentou para o fato de que o prefeito Serzedelo Correia impôs aos donos de cinematógrafos a restrição de não exibir filmes do "gênero alegre", sob pena de terem suas licenças cassadas e ainda de terem de pagar uma multa de 500 réis.

Algumas semanas depois, o mesmo jornal publicou outro artigo lamentando a falta de eficácia das medidas do prefeito:

A industria da pornographia, abertamente exercida nos cinematographos genero livre, vae tomando um incremento assustador. Já não bastavam as sordidas espeluncas, onde a mais licenciosa tavolagem é permittida pela policia. Era preciso que surgisse essa industria nova, explorada em edificios situados no centro da cidade, amplamente illuminados a luz electrica, tendo á porta $o$ indefectivel annunciador da mercadoria.

Falou-se, há dias, numa providencia, ou coisa que o valha, do sr. Serzedelo Corrêa. Essa providencia, porém, não é de effeito immediato. Os cinematographos immoraes, antes della se fazer sentir, podem, á vontade, exercer o seu negocio, com a esperança ainda de protelar ou até annullar a medida prohibitiva.

À policia competiria fechal-os, si ella andasse empenhada em cumprir as suas obrigações. 0 caso é de simples materia policial, podendo ser resolvido em menos de vinte e quatro horas.

0 sr. Leoni Ramos objectará que esses cinematographos têm licença da Prefeitura e 
satisfizeram todas as exigencias da lei. Não há duvida sobre este ponto. A Prefeitura, porém, quando as licenças lhe foram solicitadas, não teve conhecimento da especie de fitas cinematographicas que iam ser exhibidas. Si as fitas são ou não são dignas de figurar nos programmas, a policia é que deve dizer. Não é a prefeitura que vae aos theatros licenciar as peças, antes dellas serem levadas á scena, como não é ainda a Prefeitura que examina os films dos cinematographos, antes de serem annunciados.

Ainda há poucos dias, o proprietario de um cinematographo, para exhibir a fita do fuzilamento de Ferrer, teve que pedir á policia a necessaria licença, e a policia, meditando sobre o grave assumpto, acabou por marcar, segundo as suas conveniencias, o dia da exhibição. Está claro que o sr. Leoni Ramos, antes de assim determinar, não foi pedir luzes ao sr. Serzedelo Corrêa.

Da mesma forma poderia proceder relativamente aos cinematographos licenciosos. 0 incremento, que elles estão tomando, já é para esta culta cidade um deploravel attestado do valor da nossa policia. As fitas exhibidas são de uma pornographia sordida, vergonhosa, baixa...

A principio, os proprietarios desses cinematographos annunciavam que o programma era livre, a elle não podendo assistir mulheres nem creanças. Era um meio cynico de recommendar a patifaria.

Hoje, porém, certos da impunidade, limitam-se a declarar que as fitas são alegres. 0 termo presta-se a dubiedades e tem causado taes resultados que alguns cinematographos já chegam a inserir nos seus annuncios esta declaração: "AQUI NÃO SE EXHIBEM FITAS DUVIDOSAS".

É o cumulo. Deante de tudo isso, a policia nada faz e finge-se sem garantias para fechar as casas onde se explora a pornographia cinematographica ${ }^{20}$.

Mais uma vez justificando a censura por conta da proteção de mulheres e crianças do consumo de fitas pornográficas, o artigo destaca a exploração dessas fitas no circuito exibidor das áreas mais nobres da então Capital, a leniência da polícia em combatê-la e a passividade do órgão de fiscalização da Prefeitura em aplicar sanções, o que era motivo de espanto para o autor. Ainda, o artigo indica que cabia à polícia a atividade censora à época. Revela-se sobre que entidade se projeta o ideal de ordem da Primeira República e que, em oposição a ele, não consegue atingir as expectativas dos cronistas dos jornais cariocas.

Ademais, o artigo lida com a pornografia nos dois níveis de poluição apontados por Douglas (1976). Ao criticar a exploração desta nas áreas centrais da cidade, a autora apela à dimensão instrumental da poluição, isto é, à capacidade que esta possui de criar e influenciar comportamentos. Em paralelo, ao sublinhar que cabia aos vigilantes da ordem manter as obras pornográficas interditadas, também lidava 
com a dimensão de perigo que este consumo representava ao ideal de honra sexual vigente à época e, em particular, a quem transgredisse a norma de fruí-la.

As propostas encampadas pelo prefeito Serzedelo Correia encontraram ressonância nos anos seguintes. Em outras fontes dos anos seguintes, é possível se deparar com propostas similares às feitas nas páginas do Correio da Manhã. A título de exemplo, podemos citar o artigo O cinema obsceno, publicado na Gazeta de Notícias ${ }^{21}$, no qual o cronista elogia a iniciativa do intendente Leite Ribeiro de lançar proposta para proibir a exibição de filmes pornográficos, o que indica que esta questão permanecia como uma preocupação dos jornais da época. Embora alvo de constrangimentos, os filmes pornográficos continuavam a ser explorados pelos exibidores de cinema e apreciados pelo público carioca das primeiras décadas do século XX.

Assim, o acesso a essas fitas situava-se numa zona ambígua entre o legalmente proibido/ rechaçado e a permissividade que consentia não somente a exploração comercial desses filmes, como também a circulação dos repertórios dessas fitas através de diferentes sujeitos e grupos, com ressonâncias na produção jornalística-editorial (de revistas de cunho pornográfico, de contos eróticos publicados em jornais dentro de alguns limites impostos pela censura), literária (crônicas e romances pornográficos) e teatral.

Em paralelo à exibição de filmes pornográficos, dois elementos apareciam combinados a ela na lista de preocupações das autoridades: o jogo e a prostituição. Recuperando um trecho do primeiro artigo publicado no Correio da Manhã, no qual o autor diz que "a policia actual não acha inconveniente na pornographia ás escancaras, como considera a coisa mais natural do mundo que o Rio de Janeiro esteja transformado na cidade, por excellencia, do jogo, na Monaco americana"22 transparece-se esta ligação comumente feita à época. Na coluna Queixas e reclamações do jornal O Paiz, um leitor alertou os jornalistas sobre a existência de um casarão na rua Chaves Faria $^{23}$ que explorava prostituição aliada à exibição de filmes pornográficos. $\mathrm{Na}$ reclamação sobre este casarão, o leitor indignado ressalta que "as familias que têm a infelicidade de morar nas inmediações, já não 
chegam ás suas janelas, não evitando, mesmo assim, ouvir de quando em vez, as obscenidades que, com a maior naturalidade e em altas vozes, são pronunciadas"24. Mais uma vez, o domínio do excesso aparece como algo a ser rechaçado da vida pública do período.

Além destas associações, o combate à pornografia também incidiu na rixa entre teatro e cinema. Devido a uma série de disputas comerciais em torno da conquista do público, essas duas formas de entretenimento foram muitas vezes vistas de modo dicotômico pelos cronistas dos periódicos do início do século XX. Por conta das variações bruscas nas receitas graças à inflação, da queda de público e da crise criativa que se abateu sobre o meio teatral, provocando inclusive o fechamento de várias companhias, alguns artistas e empresários do ramo viam com extrema desconfiança e ressentimento o cinematógrafo. A percepção de que o novo meio "roubava" o público de um divertimento mais "legítimo", " de alto padrão" era bastante veiculada pela imprensa à época. À "baixeza”, à "frugalidade" e à "falta de espírito" do cinematógrafo, os defensores do teatro opunham a pretensa contenção, seriedade e cultivo do espírito proporcionado por esta arte.
Em se tratando de pornografia, os defensores do teatro acusavam o cinematógrafo de explorá-la ao extremo do mau gosto na disputa pelo público. Além disso, dirigiam à censura feita pela polícia e à fiscalização municipal o ressentimento de que estas eram extremamente rigorosas com as peças teatrais e, em contrapartida, complacentes com as fitas. Por fim, ainda chamavam a atenção do próprio público, afirmando que este tinha uma avaliação dúbia em relação ao teatro e ao cinematógrafo. Nas palavras de um cronista mordaz publicado na revista Fon-Fon:

Ora, esses senhores atacam o theatro livre
e permittem entretanto, com a máxima faci-
lidade, a frequencia dos cinemas, e frequen-
cia continua, como se vê, ás pessoas das
suas proprias familias, irmãs, filhas, etc.,
por quem, dizem elles, pugnam quando
as impedem de ir a um theatro em que se
exhiba peça do gênero chamado livre.

E o mais interessante é que para o cinematographo, elles chegam até a convidal-as ${ }^{25}$.

Vários empresários do entretenimento carioca que exploravam tanto o teatro quanto o cinema foram alvos de artigos nos jornais criticando-os por explorar a exibição de fitas "do gênero alegre". Por ocasião de um protesto de estudantes contra o exibidor 
Giacomo Staffa, os editoriais dos jornais destacaram a "má frequência" de sua sala de cinema graças à exibição de filmes de "qualidade duvidosa", um eufemismo para tratar de pornografia ${ }^{26}$.

Paschoal Segreto, o mais célebre empresário do ramo à época, também não escapou a essas acusações. Em uma das ocasiões, rebateu uma campanha feita pelo jornal Gazeta de Notícias contra suas casas de diversões, notadamente a Maison Moderne, localizada na Praça Tiradentes, na área central do Rio de Janeiro. Publicou uma carta no Jornal do Commercio antecedida por uma nota inflamada de um jornalista aliado, na qual se defendeu das acusações de exploração do jogo, das fitas pornográficas e da cumplicidade com a prostituição. Inclusive, inverteu a acusação contra a Gazeta, acusando-a de fraudar os jogos em sua casa de espetáculo ${ }^{27}$.

Em outros momentos, Segreto era defendido por empresários e outros aliados nas páginas dos jornais cariocas. Devido a uma polêmica com Arthur Azevedo, Eugenio D’Angelo, um empresário amigo de Segreto que explorava a diversão cinematográfica no Moulin Rouge ${ }^{28}$, publicou uma resposta inflamada ao então célebre dramaturgo:

A proposito das sessões de cinematographo genero livre no Moulin Rouge, o Sr. Arthur Azevedo, moralista de ultima hora, sahiu-se hontem pelo seu noticiario com ares de critica censora, protestando contra essas exhibições, a que empresta adjectivos criminosos, fomentando projecto solemne. Essas exhibições, sabe bem o publico, são feitas em toda a parte do mundo, e sob esse titulo genero livre apresenta-se uma serie de scenas grivoises, que nada offendem á moral, uma vez que não são pornographicas, como teima o mentor Arthur. [...] Mas tal não comprehende 0 adiposo critico theatral que préga como frei Thomaz, pois ao mesmo tempo que apostropha umas simples fitas cinematographicas applaude com ambas as mãos e com todo o gosto lascivo de sua babugem, os espectaculos genero livre, que as companhias theatraes exhibem, exhibiram e hão de exhibir, é onde a liberdade escancarada vai até ao facto material quase em scena aberta! É esse Catão de ultima hora quem se levanta contra umas exhibições alegres sem se lembrar, que em suas peças já representadas, não há só genero livre, há muito mais, há pornographia grossa, como no Pum, a scena do vendeiro com a mulata, encabrosamente manifestada ao publico e como nossa peça em um acto, a Almenjerra, que vai agora á scena por uma companhia italiana, e onde o Sr. Arthur faz alarde dos amores illicitos 
e remata a moralidade do seu trabalho com a mais refinada das pornographias, que offende o decoro das familias [...] $]^{29}$.

Fica evidente a preocupação do empresário em descaracterizar as projeções cinematográficas como pornográficas, ao mesmo tempo que devolve as acusações a várias peças escritas ou apreciadas positivamente por Azevedo, revelando uma hipocrisia por parte deste na apreciação das obras e no depreciar do cinematógrafo. Mesmo assim, a pornografia ainda aparece em seu aspecto negativo, no que ataca às concepções morais vigentes à época e, mais uma vez, representada como uma ameaça às famílias. Ainda, esta luta discursiva entre os defensores do teatro e do cinema situou-se dentro das expectativas dos espectadores dos estratos médios e superiores, haja vista a ênfase na defesa da família em ambos os lados.

Esta ambivalência no trato com o consumo de pornografia pode ser lida como um vestígio das tensões entre o ideal de pureza propagado pela Primeira República em relação à família, às mulheres e às crianças e o sucesso comercial das fitas (e das peças, das obras literárias, das revistas etc.) pornográficas, atestado tanto pela resistência de os exibidores cinematográficos em abrir mão desta parcela do mercado quanto do público de deixar de consumir estes produtos.

Nas fontes analisadas, esse ideal de pureza em torno da família nuclear surge como o objeto a ser protegido da poluição representada pelo consumo de pornografia e do perigo a que esta transgressão poderia levar. Gay (2002, p. 64) ponderou que "a família devia ser considerada o motivo principal da busca de sucesso material" e, a isso, acrescentou que uma série de interditos morais referentes às práticas sexuais foram consolidadas na sensibilidade burguesa, sobretudo no que tange o controle da sexualidade das mulheres.

No combate à pornografia, que finalmente pode ser percebido como uma das formas de os setores médios projetarem as tensões políticas e sociais no consumo, os jornalistas e leitores que enviavam cartas condenando-a podem ser percebidos como empreendedores morais (BECKER, 2008) do ideal de pureza em torno da honra sexual e do ideal de ordem e de nação projetados na Primeira República. Marcados por um senso comum relacionado aos estratos médios, a eles cabia difundir por este meio impresso de grande presença na vida pública do período as chaves de leitura que visavam interditar este tipo de consumo. 


\section{Considerações finais}

Ao longo do artigo, pretendemos rastrear alguns constrangimentos impostos ao consumo de obras pornográficas nos cinematógrafos do Rio de Janeiro nas primeiras décadas do século XX. Para tanto, analisamos primeiramente a quem essas interdições pretendiam proteger: mulheres e crianças das classes superiores identificadas a um projeto de nação moderna para a Primeira República.

Em seguida, verificamos como a perseguição à pornografia se coadunava com o novo projeto de metrópole para a então Capital Federal, situando-se paralelamente à repressão a elementos da cultura popular, à presença das classes sociais mais baixas nas áreas nobres do Rio de Janeiro e a práticas que manchavam o ideal de ordem vigente à época.

Além disso, recolhemos fontes a respeito das tensões entre o consumo de pornografia nos cinemas e esses projetos de cidade e de nação moderna, manifestadas nas perseguições em níveis administrativo, legal, político e judicial. Ao mesmo tempo, a permanência desta repressão em um longo espaço de tempo também foi reveladora da ambivalência no tratamento ao consumo de obras pornográficas, uma vez que pôde ser lida como o sucesso de público obtido por essas obras e a falta de eficácia na fiscalização dessas sessões por parte dos órgãos públicos. Também podemos ver neste consumo de filmes pornográficos era parte de uma identidade de classe entre jovens da elite e da classe média nascente, ao passo que jovens das classes populares tinham outras formas de acesso à pornografia (jornais e revistas mais populares).

Reconhecemos os limites na interpretação em torno do fenômeno da pornografia no período abordado pela ausência de alguns tipos de fontes e enfatizamos que o principal critério para a escolha das fontes aqui expostas foi o fato de elas partilharem, em algum nível, sinais que evidenciam como a censura operou em sua legitimidade social e como revelaram algumas tensões sociais latentes. Ainda, foi possível verificar nessas fontes vestígios de uma realidade social contraditória e permeada de ambiguidades, cujo registro textual permite-nos um acesso inicial.

Constatamos que o debate sobre interdição de filmes pornográficos foi perpassado pelas duas dimensões da poluição apontadas por Douglas (1976), na medida em que este visa tanto a influenciar o comportamento alheio à não fruição dessas obras quanto a apontar os perigos existentes na transgressão do ideal de ordem. Em consequência, lidamos com os dois níveis apontados na nossa hipótese inicial de que a poluição dizia respeito tanto ao ritual de ir ao cinema quanto às concepções 
de honra sexual e de ordem em voga durante o período abordado.

Finalmente, foi necessário apontar como a pornografia foi articulada nas disputas comerciais entre o teatro e o cinematógrafo, sobretudo considerando o contraste entre a legitimidade cultural e a crise financeira que o primeiro enfrentava. Desse modo, o cinematógrafo era representado como um elemento da "baixa cultura" e precisou entrar nessa luta discursiva (através de seus agentes e aliados na imprensa) para se afirmar financeira, cultural e socialmente como um hábito de lazer entre os moradores do Rio de Janeiro.

\section{Referências}

ABREU, Martha. Meninas perdidas. In: DEL PRIORE, Mary (Org.). História das crianças no Brasil. São Paulo: Contexto, 2016. p. 289316.

ARAÚJO, Vicente de P. A Bela Época do cinema brasileiro. São Paulo: Perspectiva, 1985.

BARBOSA, Marialva C. História cultural da imprensa: Brasil, 1900-2000. Rio de Janeiro: Mauad X, 2007.

BECKER, Howard. Outsiders: estudos de sociologia do desvio. Rio de Janeiro: Zahar, 2008.

CAULFIELD, Sueann. Em defesa da honra: moralidade, modernidade e nação no Rio de Janeiro. Campinas: Editora da Unicamp, 2000.

CHALHOUB, Sidney. Trabalho, lar e botequim: o cotidiano dos trabalhadores no
Rio de Janeiro da belle époque. Campinas: Editora da Unicamp, 2012.

COMAROFF, John \& Jean. Ethnography and historical imagination. Oxford, Boulder: Westview Press, 1992.

DOUGLAS, Mary. Pureza e perigo. São Paulo: Perspectiva, 1976.

DOUGLAS, Mary; ISHERWOOD, Baron. 0 mundo dos bens: para uma antropologia do consumo. Rio de Janeiro: UFRJ, 2004.

EL FAR, Alessandra. Páginas de sensação: literatura popular e pornográfica no Rio de Janeiro (1870-1924). São Paulo: Cia. das Letras, 2004.

GAY, Peter. O século de Schnitzler: a formação da cultura da classe média (1815-1914). São Paulo: Cia. das Letras, 2002.

GINZBURG, Carlo. Mitos, emblemas, sinais: morfologia e história. São Paulo: Cia. das Letras, 2007a.

. O fio e os rastros: verdadeiro, falso, fictício. São Paulo: Cia das Letras, 2007b.

Microhistory: two or three things that I know about it. Critical Enquiry, Chicago, v. 20, n. 1, p. 10-35, 1993.

Os andarilhos do bem: feitiçarias e cultos agrários nos séculos XVI e XVII. São Paulo: Cia. das Letras, 1988.

HUNT, Lynn. A invenção da pornografia. São Paulo: Hedra, 1999.

KENDRICK, Walter. The secret museum: pornography in modern culture. Los Angeles: University of California Press, 1997.

LAPERA, Pedro Vinicius Asterito; SOUZA, Bruno Thebaldi de. Cinematógrafo e 
espetáculos de massa através do acervo da Biblioteca Nacional: algumas notas metodológicas. In: BRAGA, José Luiz; LOPES, Maria Immacolata Vassalo de; MARTINO, Luiz Carlos (Org.). Pesquisa empírica em Comunicação: Livro Compós 2010. São Paulo: Paulus, 2010. p. 381-401.

SCHWARCZ, Lilia M. O espetáculo das raças: cientistas, instituições e questão racial no Brasil do século XIX. São Paulo: Cia. das Letras, 2005.

SEVCENKO, Nicolau. Literatura como missão: tensões sociais e criação cultural na Primeira República. São Paulo: Brasiliense, 1983.

SINGER, Ben. Melodrama and modernity: early sensational cinema and its contexts. New York: Columbia University Press, 2001.

VIANNA, Adriana. 0 mal que se adivinha: polícia e menoridade no Rio de Janeiro. Rio de Janeiro: Arquivo Nacional, 1999. 


\section{Between "happy" and "free": pleasure and repression against pornography in Rio de Janeiro's cinemas (1907-1916)}

\section{Abstract}

This article analyses the articulations between cinematographic consumption, pornography and public in Rio de Janeiro during the Belle Époque, more precisely from two questions: in what ways the cinematographic exhibition conditioned the consumption of works considered pornographic? And how did the repression campaigns against pornography in cinemas act in this consumption? Our hipothesis is: the consumption of pornographic films was perceived as a pollution in relation to the ritual of going to the cinema. On a larger scale, this consumption can also be perceived as a pollution to the conceptions of sexual honor which were legitimated in the period. Our methodology is the indiciary paradigm, as Carlo Ginzburg exposed it. As a result, we highlight the insertion of the repression against pornography within the hygienist project for Rio de Janeiro, the disputes between theater and cinema and a morale related to the middle sectors in formation.

\section{Keywords}

Silent cinema. Pornography. Consumption.

\section{Entre "felices" y "libres": placer y represión contra la pornografía en los cines de Río de Janeiro (1907-1916)}

\section{Resumen}

Este artículo aborda las articulaciones entre el consumo cinematográfico, la pornografía y el público en Río de Janeiro durante la Belle Époque, más precisamente a partir de dos preguntas: ¿de qué manera la exposición cinematográfica condicionó el consumo de obras consideradas pornográficas? ¿Y cómo actuaron las represiones contra la pornografía en los cines sobre este consumo? Suponemos que el consumo de películas pornográficas se percibió como una contaminación en relación con el ritual de ir al cine. A mayor escala, este consumo también puede percibirse como una contaminación de las concepciones del honor sexual que prevalecen en el período. Como metodología, adoptamos el paradigma evidencial, como lo expone Carlo Ginzburg. Como resultado, destacamos la inserción de la represión contra la pornografía dentro del proyecto higienista para Río de Janeiro, las disputas entre teatro y cine y una moral presente en los sectores medios en formación.

\section{Palavras clave}

Cine mudo. Pornografía. Consumo.

\section{Pedro Vinicius Asterito Lapera}

Doutor em Comunicação pelo Programa de Pós-Graduação em Comunicação da Universidade Federal Fluminense - UFF. Pesquisador da Fundação Biblioteca Nacional FBN/MCid, Rio de Janeiro, Rio de Janeiro. Docente do Programa de Pós-Graduação em Cinema e Audiovisual da Universidade Federal Fluminense - UFF, Niterói, Rio de Janeiro, Brasil. | E-mail: plapera@gmail.com Orcid: https://orcid.org/0000-0002-7547-1566 